\title{
PELATIHAN TEKNISILABORATORIUM BIOMOLEKULER KESEHATAN MASYARAKAT PROVINSI NTT UNTUK PERSIAPAN PENANGANAN SAMPEL COVID-19 SECARA POOLED-TEST
}

\author{
Stormy Vertygo ${ }^{1}$, Fainmarinat S. Inabuy ${ }^{2)}$, Alfredo Kono ${ }^{3)}$, Ermi Ndoen ${ }^{3)}$, Dominggus Elcid Li ${ }^{3)}$
}

Politeknik Pertanian Negeri Kupang ${ }^{1)}$

Universitas Udayana ${ }^{2)}$

Forum Academia NTT ${ }^{3)}$

email: svertygo91@gmail.com ${ }^{1)}$

\begin{tabular}{|l|l|l|}
\hline Dikirim: 02-01-2021 & Direvisi: 25-01-2021 & Diterbitkan: 28-02-2021 \\
\hline
\end{tabular}

\begin{abstract}
Abstrak
Dengan semakin meningkatnya kasus terkonfirmasi positif COVID-19 di wilayah provinsi Nusa Tenggara Timur (NTT), suatu metode pemeriksaan diagnostik yang dapat menganalisa sampel dalam jumlah banyak dengan waktu singkat menjadi sangat imperatif untuk dilakukan. Menyikapi hal ini, sejumlah putra-putri NTT yang tergabung dalam organisasi Forum Academia NTT (FAN) memprakarsai penerapan metode pooled-test untuk analisa diagnostiksampel COVID-19 yang diharapkan dapat mengoptimalkan program pemerintah dalam mempercepat penanganan penyakit ini di wilayah NTT. Pada Maret 2020 lalu, sebanyak 13 teknisi laboratorium (laboran) telah berhasil diseleksi yang akan ditempatkan pada Laboratorium Biomolekuler Kesehatan Masyarakat Provinsi NTT, khususnya untuk menjalankan prosedur analisis sampel menggunakan metode tersebut di atas. Akan tetapi, sebelum para laboran ini siap beraktivitas, diperlukan suatu pelatihan khusus yang dapat membekali mereka dengan kompetensi dan keterampilan dasar yang diperlukan. Pada Juni 2020, pelatihan Biomolekuler tahap I telah dilaksanakan yang memiliki maksud dan tujuan tersebut. Topik pelatihan yang diajarkan berupa: Pengenalan Biosafety Lab dan Biosafety Cabinet, Teknik Penggunaan Mikropipet, Teknik Analisis DNA/RNA menggunakan metode Elektroforesis, NanoSpektrofotometer, PCR dan qPCR, serta Pengenalan metode Pooled-test. Berdasarkan hasil observasi, para peserta dianggap telah cukup menguasai berbagaiteknik Biomolekuler Dasar yang diajarkan yang diharapkan dapat berkontribusi terhadap hasil penanganan analisis sampel yang lebih akurat, terpercaya dan dapat dipertanggungjawabkan.
\end{abstract}

Kata Kunci: Pelatihan, Teknisi Laboratorium, Biomolekuler Dasar, COVID-19, Pooled-test

\begin{abstract}
With the increasing number of positive confirmed cases of COVID-19 in East Nusa Tenggara (NTT) province, a diagnostic test method that could analyze large numbers of samples in a short time is becoming imperative. In response to this, several NTT subjects from NTT Academia Forum (FAN) have initiated the application of pooled-test method for handling diagnostic analysis of COVID-19 samples which are expected to optimize government's program in accelerating the handling of this disease in NTT region. In March 2020, 13 laboratory technicians were successfully selected to be placed in the Biomolecular Laboratory of Public Health in NTT Province, especially to carry out
\end{abstract}


sample analysis procedure using such method. Before these technicians are ready to work, a special training is needed that can equip them with necessary basic competencies and skills. In June 2020, Phase I Biomolecular training was carried out which such aims and objectives. The training topics taught were: Introduction to Biosafety Lab and Biosafety Cabinet, MicropipettingTechnique, DNA/RNA Analysis using Electrophoresis, Nano-Spectrophotometer, PCR and qPCR, and Pooled-test method. Based on observations, the participants had sufficiently mastered various Basic Biomolecular techniques which were expected to contribute to handling more accurate, reliable, and accountable sample analysis results.

Key Words: Training, Laboratory Technicians, Basic Biomolecular, COVID-19, Pooled-test

\section{PENDAHULUAN}

Setelah dideklarasikan sebagai pandemi oleh Organisasi Kesehatan Dunia PBB (WHO) pada Maret 2020 lalu, Coronavirus Disease2019 atau Penyakit Koronavirus 2019 (COVID-19) dengan sekejap telah mengubah tatanan kehidupan manusia baik individual maupun sosial secara global ( $W H O$ Western Pacific | World Health Organization, 2020). Dampak yang begitu signifikan dari penyebaran penyakit ini telah dirasakan pada hampir segala aspek kehidupan masyarakat mulai dari bidang ekonomi, politik, pendidikan, telekomunikasi hingga mode (Chakraborty \& Biswas, 2020; Herrera et al., 2020; Prawoto et al., 2020). Penyakit ini disebabkan oleh virus zoonotik, severe acute respiratory syndrome coronavirus 2 (SARS-CoV-2), yang diduga berasal dari hewan kelelawar dan trenggiling yang umumnya dipasarkan pada pasar hewan di Wuhan, China, lokasi di mana penyebaran penyakit ini bermula (Mackenzie \& Smith, 2020). Virus ini juga merupakan varian baru dari virus SARS-CoV-1 penyebab penyakit severe acute respiratory syndrome (SARS) atau sindrom pernapasan akut berat yang pernah menjadi pandemi pada tahun 2002-2004 silam (Shereen et al., 2020).

Di Indonesia sendiri, angka penderita COVID-19 dan laju mortalitasnya kian meningkat dari hari ke hari yang memaksa pemerintah untuk memperpanjang masa penguncian (lockdown) di beberapa daerah dengan semakin memperketat kebijakan Pembatasan Sosial Berskala Besar (PSBB) khususnya di tempat-tempat umum (dob, 2020). Meskipun kasus COVID-19 di NTT terjadi kemudian bila dibandingkan dengan provinsi lainnya di Indonesia, akan tetapi angka penderita yang terkonfirmasi positif pun kian menanjak. Berdasarkan data dari Gugus Tugas Percepatan Penanganan COVID-19 NTT per tanggal 31 Desember 2020, total kasus yang terkonfirmasi positif berjumlah 2171 orang dengan 50 orang di antaranya meninggal dunia (COVID-19 NTT - Sebaran Data, 2021). Dengan mempertimbangkan cakupan luas geografis dan dinamika sosio-kultural masyarakat NTT, penyebaran penyakit ini diasumsikan dapat semakin meningkat apabila tidak ada komitmen penuh dari tiap individu untuk mematuhi protokol kesehatan yang telah ditetapkan pemerintah. Selain itu, karena penyebaran virus ini yang sangat cepat dan tak terlihat, maka diperlukan pula suatu bentuk metode pemeriksaan yang dapat menganalisis sampel dengan jumlah banyak dalam waktu singkat sehingga proses penanganan lebih lanjut, baik yang bersifat kuratif maupun preventif dapat dilakukan secara lebih efektif dan efisien.

Metode pemeriksaan secara berkelompok atau yang dikenal dengan istilah "pooled-test' merupakan suatu teknik pemeriksaan diagnostik yang menggabungkan sampel beberapa individu ke dalam satu kelompok (pool) sebelum dilakukannya proses analisis lebih lanjut (Denny, 2020). 
Implementasi metode ini dinilai dapat menangani sampel dengan ukuran yang besar khususnya terkait penanganan berbagai penyakit menular (infectious diseases) (Deckert et al., 2020). Saat ini, metode pooled-test telah diterapkan dalam analisis sampel untuk penyakit-penyakit seperti HIV/AIDS, klamidia, dan kencing nanah (gonornea) (Sultan et al., 2016).Selain itu, teknik ini dapat pula menghemat biaya analisis karena penggabungan sampel yang dilakukan hanya akan membutuhkan perangkat analisis (kit) yang setara dengan analisis untuk 1 sampel saja dengan tingkat keakuratan yang minimal sama(Health, 2020). Dengan mempertimbangkan aspek-aspek yang telah disebutkan tersebut, metode diagnostik ini dinilai dapat diterapkan terhadap analisis sampel COVID-19 karena sesuai dengan tujuan dan urgensinya saat ini. Di NTT, penerapan metode pooled-test diprakarsai oleh Fainmarinat Inabuy dan Dominggus Elcid Li yang kemudian mengusulkan proposal tersebut kepada Pemerintah Provinsi dan mendapatkan dukungan penuh serta sentimen positif dari pihak-pihak lainnya.

Sebelum metode ini dapat dijalankan, diperlukan dukungan berupa laboratorium dengan fasilitas yang menunjang yang dilengkapi pula dengan sumber daya manusia berupa teknisi laboratorium (laboran) dengan pengetahuan dan keterampilan pada level Biomolekuler yang relevan. Perekrutan terhadap laboran dengan kriteria seperti ini telah dilakukan sebelumnya dan berhasil terjaring sebanyak 13 orang. Tujuan dari pelatihan ini adalah untuk selanjutnya membekali dan mengasah keterampilan laboran-laboran yang terjaring tersebut, sebelum ditempatkan pada Laboratorium Biomolekuler Kesehatan Masyarakat Provinsi NTT untuk menangani sampel COVID-19 secara pooled-test. Dengan demikian, keterampilan yang didapatkan selama proses pelatihan ini dapat berkontribusi dalamperolehan hasil interpretasi laboratorium yang akurat, terpercaya dan dapat dipertanggungjawabkan.

\section{METODE}

Pelatihan dilakukan selama enam hari dari tanggal 15 hingga 20 Juni 2020 dengan peserta pelatihan merupakan teknisi (laboran) hasil perekrutan lembaga Forum Academia NTT (FAN) dan Institute of Resource Governance and Social Change (IRGSC) Kupang sejumlah 13 orang dengan latar belakang pendidikan dan keterampilan yang sesuai. Laboran-laboraninikemudian akan ditempatkan pada Laboratorium Biomolekuler Kesehatan Masyarakat (KesMas) Provinsi NTT, khususnya dalam penanganan analisis sampel swab COVID-19 dengan menggunakan metode pooled-test. Pada saat itu, laboratorium Biomolekuler yang dimaksud masih dalam tahap perencanaan untuk dibangun, sehingga proses pelatihan dilaksanakan di laboratorium Bioteknologi Pertanian, jurusan Tanaman Pangan dan Hortikultura (TPH), Politeknik Pertanian Negeri Kupang (Politani Kupang).

Topik-topik pelatihan memiliki cakupan di bidang Biomolekuler yang dapat membekali para laboran dalam menjalankan berbagai aktivitas di lab khususnya terkait analisis sampel COVID-19, di antaranya: Pengenalan dan Penggunaan Biosafety Lab dan Biosafety Cabinet, Teknik Penggunaan Mikropipet, Teknik Analisis DNA/RNA menggunakan metode Elektroforesis, Nano-Spektrofotometer, PCR dan qPCR, Pengenalan konsep analisis sampel COVID-19 menggunakan metode Pooled-test serta 
diskusi singkat mengenai perkembangan wabah COVID-19 di NTT dalam perspektif epidemiologi. Pelatihan diawali dengan penjelasan singkat secara teoritis yang kemudian diikuti dengan pendalaman praktis menggunakan alat, bahan serta fasilitas yang telah tersedia dalam laboratorium.

\section{HASIL DAN PEMBAHASAN}

\section{Pengenalan Biosafety Lab dan Biosafety Cabinet}

Sebagai pengantar, para peserta diperkenalkan terlebih dahulu dengan konsep Biosafety Lab yang merupakan serangkaian protokol yang terintegrasi di dalam laboratorium yang memiliki fungsi proteksi terhadap kontaminasi mikroorganisme patogen tidak hanya bagi personil lab, tetapi juga terhadap lingkungan internal maupun eksternal lab (World Health Organization, 2004). Para peserta diberikan pemahaman akan pentingnya bekerja di dalam laboratorium yang harus menganut dan menerapkan prinsipprinsip Biosafety (minimal Biosafety Lab level-2), khususnya dalam hal penanganan sampel COVID-19 (Mcleod, 2010). Selain itu, Biosafety kabinet sebagai salah satu fasilitas utama dalam Biosafety Lab juga dijelaskan yang akan berguna selama teknis pengerjaan sampel nantinya (khususnya saat ekstrasi material genetik virus) sehingga akan menghasilkan kualitas sampel yang baik untuk interpretasi hasil analisis yang akurat (Sapkota, 2020).

\section{Teknik Penggunaan Mikropipet}

Peserta diperkenalkan dengan alat Mikropipet, bagian-bagian beserta fungsinya. Miropipet merupakan apparatus laboratorium yang berfungsi untuk mengambil dan memindahkan suatu larutan atau cairan dengan skala volume yang sangat kecil (kurang dari $1000 \mu \mathrm{L}$ ). Terdapat berbagai jenis mikropipet berdasarkan ukuran skala volumenya. Pada pelatihan ini, para laboran menggunakan 4 jenis mikropipet dengan rentangan skala yang berbeda yaitu (SEP, n.d.):

$$
\begin{array}{ll}
\text { P10 dengan skala } & : 0.5-10 \mu \mathrm{L} \\
\text { P20 dengan skala } & : 2-20 \mu \mathrm{L} \\
\text { P200 dengan skala } & : 20-200 \mu \mathrm{L} \\
\text { P1000 dengan skala: } & 200-1000 \mu \mathrm{L}
\end{array}
$$

Dengan muara pelatihan ini yang berakhir pada pelaksanaan pooled-test untuk pendeteksian COVID-19, penggunaan mikropipet merupakan topik yang dibahas pada hari pertama sebagai salah satu kompetensi dasar awal yang dibutuhkan. Hal ini dikarenakan oleh kesalahan dalam teknik pemipetan akan dapat memberikan implikasi sistemik pada analisis tahap-tahap lanjutan selama pooled-test. Pada dasarnya, para peserta telah mengetahui cara menggunakan mikropipet dalam hal kalibrasi skala volume, pengambilan dan pemindahan cairan/larutan, akan tetapi perlu dilakukan penguatan dan 
pembiasaan kembali keterampilan penggunaannya secara baik dan benar. Secara lebih

Commented [WU1]: Tampilkan kalimat rujukan gambar mendetail, prosedur pengaturan mikropipet dapat dilihat pada Gambar 1. di bawah ini.

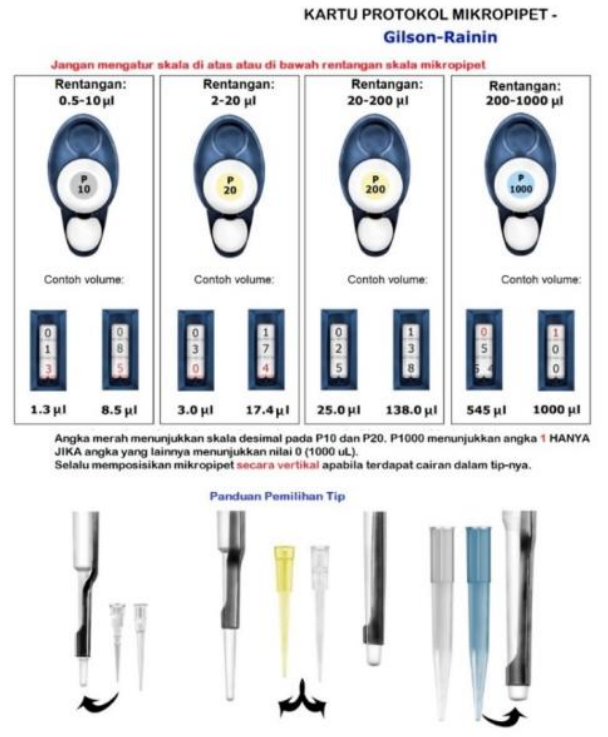

Gambar 1. Kartu Protokol Mikropipet (Sumber: SEP, n.d.)

Pada Sesi 2), peserta dilatih teknik pengambilan sampel larutan baik dalam bentuk encer (berupa akuades) dan kental (berupa gliserol 50\% dan 100\%) dengan dasar pertimbangan bahwa kedua bentuk larutan ini akan memerlukan teknik pengambilan yang berbeda (Gambar 2.). Khusus untuk pengambilan larutan kental, setelah selesai menarik tombol penekan (plunger button) mikropipet, umumnya harus menunggu beberapa detik terlebih dahulu sebelum mikropipet dipindahkan ke wadah berikut, karena larutan kental umumnya membutuhkan waktu yang lebih lama untuk tertarik ke dalam tip. Hal ini penting sebab tentunya akan sangat berpengaruh terhadap volume dan/atau konsentrasi akhir dari sampel yang diambil nantinya. Selain itu, konsistensi selama pemipetan juga diasah melalui pengambilan setiap sampel cairan/larutan (akuades, gliserol $50 \%$ dan $100 \%)$ sebanyak sepuluh kali $(10 \times)$ dan diukur massanya dengan timbangan analitik. Berdasarkan evaluasi, $70 \%$ peserta telah dapat memipet dengan volume yang cukup sama pada 10 kali pemipetan pertama, yang terlihat dari nilai massa yang tertera pada timbangan analitik yang cenderung konstan. Akan tetapi, habituasi penggunaan mikropipet ini terus dipantau secara intensif oleh para pelatih (pemateri) hingga seluruh 
peserta $(100 \%)$ telah lebih terbiasa menggunakannya dan dapat mengambil sampel dengan volume yang konstan setiap kali pemipetan (Using a Micropipette - Diamantina Institute - University of Queensland, 2017).

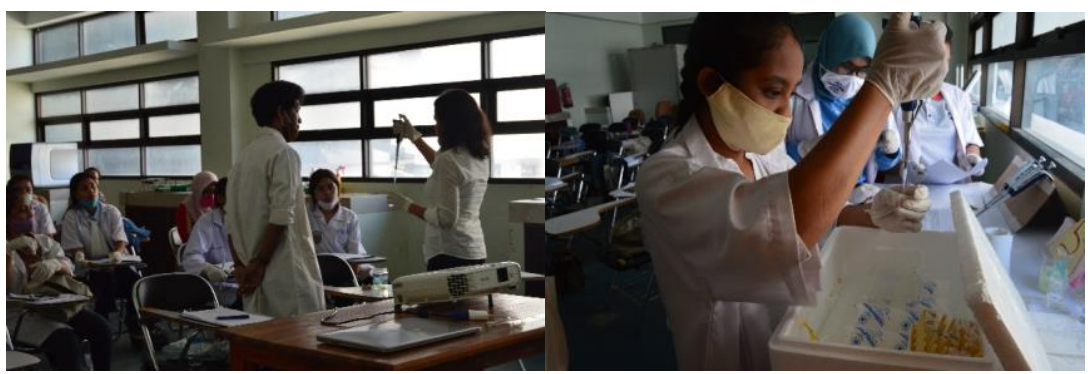

Gambar 2. Teknik Penggunaan Mikropipet. Penjelasan teoritis (kiri), praktik oleh salah satu peserta pelatihan (kanan).

Selama pelatihan teknik pemipetan ini pula, beberapa hal turut ditekankan oleh para pemateri di antaranya: meminimalisir terbentuknya gelembung dalam tip, selalu memposisikan mikropipet dalam kondisi vertikal terlebih ketika tip dalam kondisi terisi, selalu menggunakan sarung tangan terutama ketika berhubungan dengan pengerjaan sampel RNA, mengusahakan untuk menggunakan dan mengambil larutan secara aseptis dan selalu mengembalikan skala mikropipet ke posisi volume maksimum setelah selesai digunakan (maintenance).

\section{Isolasi Sampel RNA}

Pada topik ini, peserta mempraktekkan prosedur pengisolasian RNA menggunakan protokol standar pengisolasian SARS-CoV-2 yang merupakan jenis virus RNA. Akan tetapi, sebagai contoh model pelatihan, sampel yang digunakan berupa kultur bakteri Lactobacillus sp. yang telah diremajakan (refresh) selama 24 jam (Gambar 3.). Sebelum dipraktekkan, para laboran diberikan pemahaman mengenai konsep dasar tentang materi genetik (DNA dan RNA). RNA merupakan molekul kompleks yang berperan dalam proses sintesis protein seluler dan sebagai penyimpan informasi genetik (menggantikan DNA) pada beberapa strain virus. Akan tetapi, bila dibandingkan dengan DNA, RNA beruntai tunggal dan relatif lebih pendek dan tidak stabil (DNA and RNA Introduction to Chemistry, n.d.). 


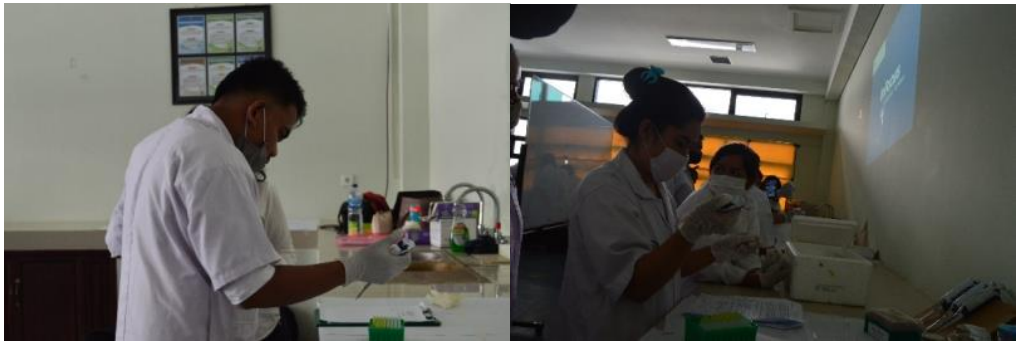

Gambar 3. Praktik Isolasi RNA

Di dalam laboratorium, untuk mendapatkan RNA berkualitas tinggi dapat menjadi suatu tantangan. Alasan utama adalah enzim yang mendegradasi RNA, ribonuklease (RNase) terdapat di mana-mana mulai dari kulit, debu, reagen yang digunakan dan bahkan dari sampel itu sendiri. Dengan demikian, menciptakan lingkungan yang bebas RNase sangat penting ketika bekerja dengan sampel RNA. Beberapa cara atau pendekatan yang dapat dilakukan untuk menciptakan lingkungan kerja yang bebas dari RNAase misalnya: penggunaan sarung tangan, pemakaian air DEPC (DEPC-treated water) dan reagen bebas RNAase, penambahan inhibitor RNA, teknik aseptik yang baik dan benar serta metode penyimpanan RNA yang efektif (Working with RNA: Hints and Tips $\mid$ Bioline | Meridian Bioscience, 2020).

Prosedur pengisolasian sampel RNA yang dilakukan saat pelatihan mengikuti protokol berikut (Qiagen, 2012):

1. Sarung tangan digunakan terlebih dahulu.

2. Kultur bakteri diambil dengan cara sentrifugasi pada $5000 \mathrm{x}$ g selama 5 menit pada suhu $4^{\circ} \mathrm{C}$ (jangan gunakan lebih dari $1 \times 10^{9}$ bakteri). Supernatan dituang, dan dengan hati-hati dikeluarkan semua media yang tersisa dengan aspirasi. Jika sentrifugasi akan digunakan nanti dalam prosedur ini, dipanaskan hingga 20 $25^{\circ} \mathrm{C}$.

3. Volume Buffer RLT ditambahkan yang sesuai Vorteks selama 5-10 detik.

\section{Jumlah bakteri}

$<5 \times 10^{8}$

$5 \times 10^{8}-1 \times 10^{9}$

\section{Buffer RLT $(\boldsymbol{\mu L})$}

700

4. Suspensi ditempatkan ke dalam tabung sentrifugasi (safe-lock tube). Tambahkan dengan reagen yang dapat melisis bakteri (ex: TissueLyser) dan sentrifugasi dengan kecepatan maksimum selama 5 menit.

5. Disentrifugasi lagi pada kecepatan maksimum selama 10 menit lalu dipindahkan suspensi ke dalam tabung yang baru yang ukurannya minimal $2 \mathrm{x}$ lebih besar dari ukuran volume Buffer RLT yang akan digunakan. 
6. Volume supernatan yang ingin digunakan ditentukan, lalu ditambahkan ethanol $70 \%$. Dengan volume yang sama dengan supernatan. Campuran dihomogenkan dengan pipetting (up-down). Jangan di-sentrifugasi.

7. Lisat ditransfer hingga $700 \mu \mathrm{L}$, termasuk endapan apa pun yang mungkin telah terbentuk ke kolom spin RNeasy yang ditempatkan ke dalam collection tube 2 $\mathrm{ml}$. Ditutup dengan hati-hati, dan disentrifugasi selama 15 detik pada kecepatan $\geq 8000 \times \mathrm{g}$ ( $\geq 10.000 \mathrm{rpm})$. Flow-through dibuang.

8. Sebanyak $700 \mu \mathrm{L}$ buffer RW1 ditambahkan ke dalam spin-column RNeasy dan campuran disentrifugasi (>10.000 rpm; 15 detik).

9. Cairan (flow-through) yang berada di tabung koleksi dibuang dan spin-column dipasang kembali pada tabung koleksi.

10. Sebanyak $500 \mu \mathrm{L}$ buffer RPE ditambahkan ke dalam membran spin-column RNeasy dan disentrifugasi (>10.000 rpm; 15 detik).

11. Cairan yang berada di tabung koleksi dibuang dan spin-column dipasang kembali pada tabung koleksi.

12. Sebanyak $500 \mu \mathrm{L}$ buffer RPE ditambahkan ke dalam spin-column RNeasy dan campuran disentrifugasi (>10.000 rpm; 2 menit).

13. Cairan yang berada di tabung koleksi dibuang dan spin-column dipasang ke dalam tabung koleksi $2 \mathrm{~mL}$ yang baru.

14. Optional: Dapat disentrifugasi pada kecepatan maksimum selama 1 menit.

15. Sebanyak 30-50 $\mu \mathrm{L}$ air bebas RNase atau air yang telah diberi DEPC ditambahkan ke filter membran spin-column dan disentrifugasi (>10.000 rpm; 1 menit).

16. Jika hasil RNA yang diharapkan adalah $>30 \mu \mathrm{g}$, ulangi langkah 15 menggunakan 30-50 $\mu \mathrm{L}$ RNase free-water atau dapat pula menggunakan eluat yang terbentuk dari langkah 15 (jika konsentrasi RNA tinggi yang diperlukan). Gunakan kembali collection tube dari langkah 15.

17. Spin-column RNeasy dibuang dan collection tube dapat disimpan pada suhu $80^{\circ} \mathrm{C}$.

18. Kualitas dan kuantitas hasil isolasi RNA dapat diperkirakan melalui elektroforesis gel agarosa $1 \%$ dan pengukuran menggunakan NanoSpektrophotometer.

19. Rasio A260/A280 yang berkisar 1.8 - 2.1 mengindikasikan bahwa sampel RNA yang diperoleh telah memiliki tingkat kemurnian yang tinggi (highly purified). 


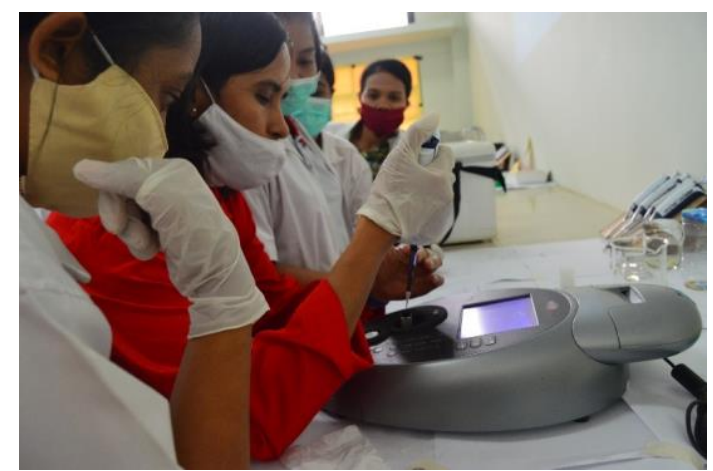

Gambar 4. Asesmen Kualitas RNA Menggunakan Nano-Spektrofotometer.

Berdasarkan hasil praktikum selama pelatihan hari ke-2 Sesi 2), sampel RNA bakteri yang di-ekstraksi dari tiap kelompok peserta memiliki rasio A260/A280 berkisar antara 1.5 sehingga dianggap memiliki tingkat kemurnian yang rendah (Gambar 4.). Salah satu penyebab ketidakmurnian ini dapat berasal dari prosedurnya sendiri yang sebagian besarnya memang diperuntukkan bagi sampel virus COVID-19. Hal ini tentunya tidak sesuai bagi ekstraksi sampel bakteri yang kemudian akan berdampak pada tidak optimalnya molekul RNA yang di-isolasi. Meskipun demikian, terhadap para peserta pelatihan, prosedur pelaksanaan metode ekstraksi RNA merupakan aspek yang lebih ditekankan untuk dipahami sehingga ketika akan berhubungan dengan sampel yang sebenarnya (SARS-CoV-2), mereka telah dapat mempraktekkan prosedurnya secara lebih efektif dan efisien sesuai protokol kesehatan.

\section{Polymerase Chain Reaction (PCR) dan Quantitative Polymerase Chain Reaction ( $q$ PCR)}

Topik selanjutnya yang dipelajari para peserta laboran adalah Polymerase Chain Reaction (PCR) dan Quantitative Polymerase Chain Reaction ( $q$ PCR)yang merupakan teknik laboratorium yang digunakan untuk membuat banyak salinan (amplifikasi) dari segmen gen tertentu yang ingin dikaji secara lebih spesifik (Gambar 5.). Tujuan utama PCR adalah untuk memperoleh gen target dengan kuantitas yang cukup (amplicon) sehingga dapat dianalisis dan/atau digunakan pada metode-metode lanjutan. Dalam pooled-test, PCR dapat dijadikan metode pendeteksian COVID-19 apabila dipadupadankan dengan metode elektroforesis (akan dibahas pada sub-topik berikutnya). Berbeda dengan dengan PCR yang bersifat kualitatif, qPCR sifatnya kuantitatif sehingga tidak diperlukan lagi kombinasi dengan metode elektroforesis karena penentuan amplicon telah terintegrasi pada setiap siklus amplifikasi (What Is the Difference between PCR and 
Real-Time PCR? | AAT Bioquest, 2020). Meskipun demikian, penentuan dan penyiapan reaksinya memiliki prosedur yang sama (termasuk setingan profil PCR-nya) (Gambar 6.).

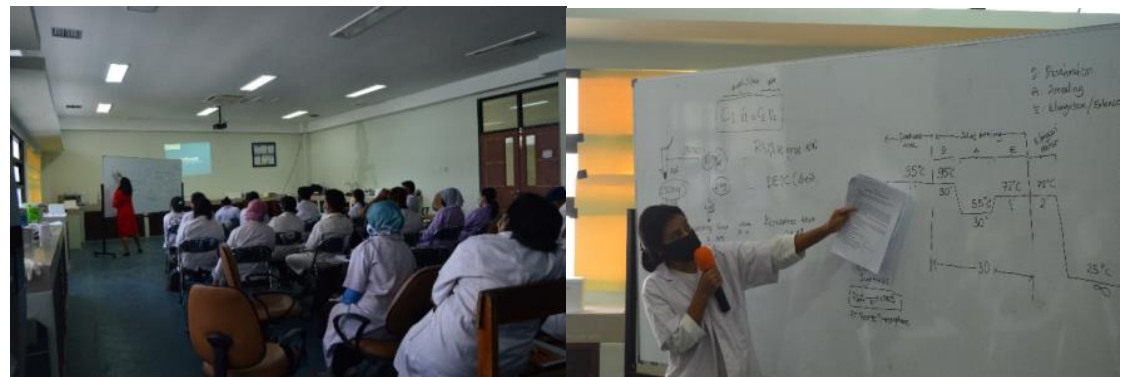

Gambar 5. Sesi Pelatihan PCR dan qPCR. Penjelasan teoritis oleh pemateri (kiri) dan oleh salah satu peserta (kanan).

Prosedur metode PCR dan qPCR yang dilaksanakan selama pelatihan adalah sebagai berikut (Nolan et al., 2013):

\section{Sintesis cDNA}

1. Tentukan jumlah reaksi yang diperlukan, termasuk kontrol. Hitung volume masing-masing komponen yang diperlukan untuk semua reaksi (berikan $\pm 10 \%$ ekstra untuk kesalahan pemipetan) dan campurkan reagen sesuai tabel di bawah ini menggunakan tabung $0,2 \mathrm{~mL}$ atau pelat 96 sumur yang diletakkan di atas es. Jika menggunakan pelat PCR, ikuti skema pelat untuk memastikan bahwa reagen ditambahkan ke sumur yang benar. Aturan pencampuran reaksi PCR (reaction mix) dapat dilihat pada Tabel 1. berikut.

Tabel 1. Reaction Mix PCR

\begin{tabular}{|c|c|}
\hline Reagen & $\begin{array}{lcc}\text { Volume } & (\mu \mathrm{L}) & \text { per } \\
\text { Reaksi } & 20 & \mu \mathrm{L} \\
\text { Tunggal } & & \\
\end{array}$ \\
\hline Campuran sintesis cDNA $(5 \times$ RT blend $)$ & 4 \\
\hline $\begin{array}{l}\text { Template Total RNA-bervariasi }(1 \mu \mathrm{g}-10 \\
\text { pg) }\end{array}$ & 1 \\
\hline PCR grade water & 15 \\
\hline
\end{tabular}

2. Setelah ditutup/disegel, campuran reaksi di-vorteks dan di-sentrifugsi sebentar untuk mengumpulkan pelet di bagian bawah tabung.

3. Campuran reaksi kemudian di-inkubasi pada suhu ruang selama 5 menit.

4. Setelah menyelesaikan sintesis cDNA, 1: 5 hingga 1:10 dari reaksi untai pertama $(2-4 \mu \mathrm{L})$ digunakan untuk amplifikasi PCR. 


\section{Amplifikasi cDNA}

1. Dalam tabung mikrosentrifuge steril $0,5 \mathrm{~mL}$, tabung amplifikasi, atau sumur pelat mikrotiter steril, larutan reaksi dicampurkan dengan urutan pada Tabel 2. berikut:

Tabel 2. PCR Mix

\begin{tabular}{|c|c|c|}
\hline Komponen & Volume & $\begin{array}{c}\text { Konsentrasi } \\
\text { Akhir } \\
\left(\mathrm{V}_{1} \mathrm{M}_{1} \cdot \mathrm{V}_{2} \mathrm{M}_{2}\right) \\
\end{array}$ \\
\hline Buffer Aplifikasi (10×) & $5 \mu \mathrm{L}$ & \\
\hline $\begin{array}{l}\text { C.0) } \\
\text { Campuran dNTP (masing-masing } 20 \mathrm{mM}, \mathrm{pH}\end{array}$ & $1 \mu \mathrm{L}$ & $0.4 \mathrm{mM}$ \\
\hline Forward primer $(20 \mu \mathrm{M})$ & $2.5 \mu \mathrm{L}$ & $1 \mu \mathrm{M}$ \\
\hline Reverse primer $(20 \mu \mathrm{M})$ & $2.5 \mu \mathrm{L}$ & $1 \mu \mathrm{M}$ \\
\hline $\begin{array}{l}\begin{array}{l}\text { Thermostable DNA taq polymerase (1-5 } \\
\text { units } / \mu \mathrm{L})\end{array} \\
\end{array}$ & & \\
\hline Template DNA & $5-10 \mu \mathrm{L}$ & \\
\hline $\mathrm{H}_{2} \mathrm{O}$ & $\begin{array}{l}\text { hingga } \\
\text { volume akhir: } \\
50 \mu \mathrm{L}\end{array}$ & \\
\hline
\end{tabular}

2. cDNA diamplifikasi menggunakan PCR dengan rincian pada Tabel 3 . berikut:

Tabel 3. Profil PCR

\begin{tabular}{||c||l|l|ll||}
\hline $\begin{array}{l}\text { Jumlah } \\
\text { Siklus }\end{array}$ & Denaturation & Annealing & Polymerization \\
\hline \hline $1-30$ & $\begin{array}{l}30 \text { detik pada } \\
94^{\circ} \mathrm{C}\end{array}$ & $\begin{array}{l}30 \text { detik pada } \\
55^{\circ} \mathrm{C}\end{array}$ & $\begin{array}{l}1 \text { menit pada } \\
72^{\circ} \mathrm{C}\end{array}$ \\
\hline
\end{tabular}




\begin{tabular}{||l||l|l||l||}
\hline $\begin{array}{l}\text { Jumlah } \\
\text { Siklus }\end{array}$ & Denaturation & Annealing & Polymerization \\
\hline \hline $\begin{array}{l}\text { Siklus } \\
\text { Terakhir }\end{array}$ & $\begin{array}{l}1 \text { menit pada } \\
94^{\circ} \mathrm{C}\end{array}$ & $\begin{array}{l}30 \text { detik pada } \\
55^{\circ} \mathrm{C}\end{array}$ & $\begin{array}{l}1 \text { menit pada } \\
72^{\circ} \mathrm{C}\end{array}$ \\
\hline
\end{tabular}

3. Sampel sebanyak 5-10 $\mu \mathrm{L}$ dari campuran reaksi uji dan masing-masing dari empat reaksi kontrol diuji dengan elektroforesis melalui agarosa atau gel poliakrilamida. Dipastikan untuk memasukkan penanda DNA dengan ukuran yang sesuai. Gel diwarnai dengan ethidium bromide ataupun SYBR Gold untuk memvisualisasikan DNA target.

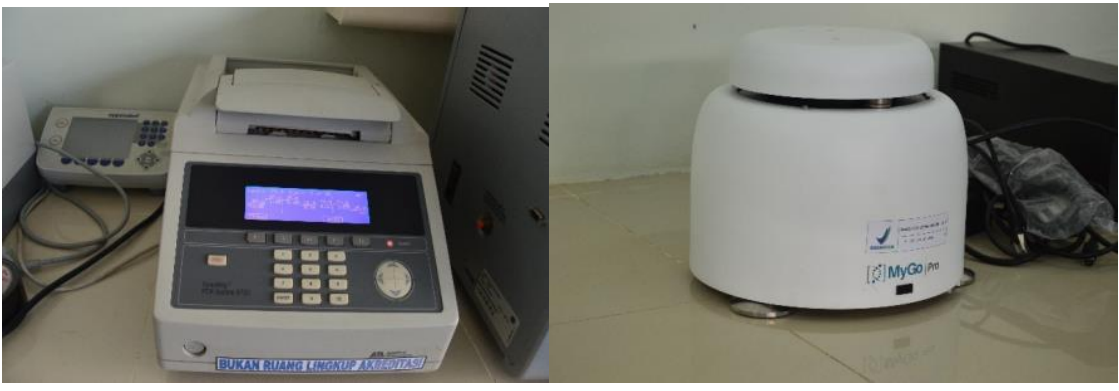

Gambar 6. Sesi Pelatihan PCR dan qPCR. Alat PCR (kiri) dan qPCR (kanan).

\section{Elektroforesis}

Gel elektroforesis merupakan teknik yang umum digunakan di laboratorium untuk memisahkan molekul bermuatan seperti DNA, RNA dan protein sesuai dengan ukurannya. Molekul bermuatan bergerak melalui gel ketika arus listrik dilewatkan di atasnya. Arus listrik diterapkan melintasi agar (gel) sehingga salah satu ujung gel memiliki muatan positif dan ujung lainnya memiliki muatan negatif. Pergerakan molekul bermuatan ini disebut migrasi. Molekul bermigrasi ke arah muatan yang berlawanan. Molekul dengan muatan negatif karena itu akan ditarik ke arah ujung positif (Fritsch \& Krause, 2003).

Molekul yang lebih kecil bermigrasi melalui gel lebih cepat dan karena itu bergerak lebih jauh daripada fragmen yang lebih besar yang bermigrasi lebih lambat dan karenanya akan menempuh jarak yang lebih pendek. Akibatnya molekul-molekul dipisahkan oleh ukuran (Lee et al., 2012). 


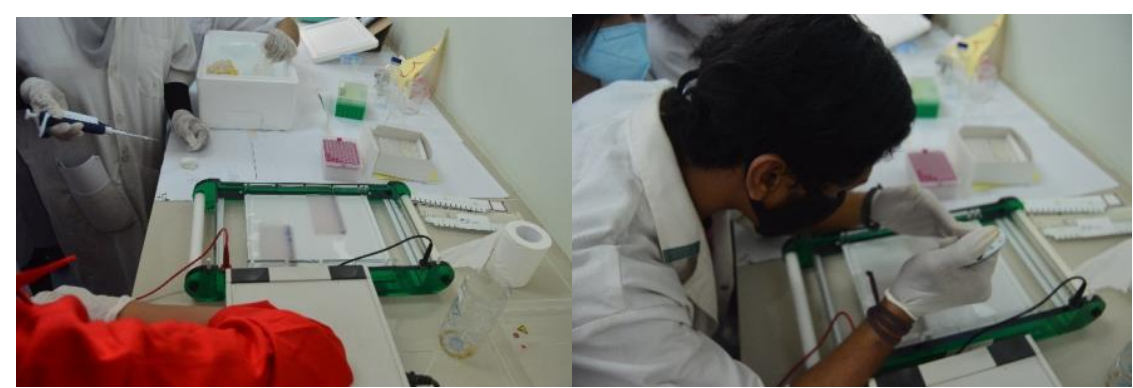

Gambar 7. Sesi Pelatihan Elektroforesis. Perakitan alat (kiri) dan loading sampel (kanan).

Selama pelatihan, para peserta tidak hanya diajarkan bagaimana teknik menempatkan sampel pada sumur elektroforesis namun juga dalam hal menyiapkan larutan buffer TBE (Tris-borate-EDTA), larutan agarose 1\% dan merangkaikan perangkat elektroforesis gel. Setelah sampel di-elektroforesis $( \pm 2$ jam $)$, agarose gel diamati di bawah UV-doc. Sesi pelatihan metode Elektroforesis daapt di lihat pada Gambar 7. di atas.

\section{Metode Pooled-test}

Pada hari terakhir pelatihan, peserta diperkenalkan dengan metode pooled-testyang akan menjadi metode utama saat mengimplementasikan prosedur analisis sampel swab COVID-19. Pada dasarnya, metode ini menggabungkan beberapa sub-sampel (yang berasal dari beberapa individu) yang dianalisis ke dalam satupool atau kelompok yang sama (CDC, 2020). Dengan demikian, kapasitas analisis sampel dapat ditingkatan sehingga penanganan lebih lanjut baik secara kuratif (misalnya: rawat inap di rumah sakit) maupun preventif (misalnya: lockdown terbatas, karantina/isolasi mandiri) daapt dilaukan secara lebih optimal. Dengan prosedur seperti ini, diharapkan juga untuk dapat menekan anggaran pengadaan perangkat tes, yang tentunya akan menekan pula biaya tes bagi masyarakat khususnya yang berasal dari golongan ekonomi tingkat menengah ke bawah (Mutesa et al., 2021). Akan tetapi, selama pelatihan, topik ini tidak dilanjutkan ke dalam bentuk latihan praktis dengan mempertimbangkan bahwa masih perlu untuk dilakukannya validasi metode pooled-test COVID-19 (yang akan lebih efektif dilakukan ketika Lab Biomolekuler selesai dibangun) untuk mengidentifikasi berapa total maksimum sub-sampel yang dapat digabungkan ke dalam satu pool untuk meminimalisir kemungkinan diperolehnya hasil analisis yang negatif palsu.

\section{Perkembangan Wabah COVID-19 di NTT dalam Perspektif Epidemiologi}

Sesi pelatihan diakhiri dengan diskusi singkat antara salah satu pemateri dengan para peserta terkait perkembangan wabah COVID-19 di NTT dalam perspektif epidemiologi. Salah 
satu topik yang didiskuskan adalah mengenai bagaimana untuk sebelum melonggarkan pembatasan dan transisi maka harus memastikan terlebih dahulu beberapa hal di antaranya: bukti penularan penyakit terkendali, sistem kesehatan yang dapat mendeteksi, menguji, mengisolasi, serta menangani setiap kasus dan melacak setiap kontak, risiko zona merah diminimalkan di tempat-tempat rentan seperti panti jompo, sekolah, tempat kerja dan tempat umumlainnya telah menetapkan langkah-langkah pencegahan, risiko mengimpor kausus baru dapat dikelola, masyarakat sepenuhnya dididik, dilibatkan, diberdayakan untuk hidup di "The New Normal" (Ndoen, 2020).

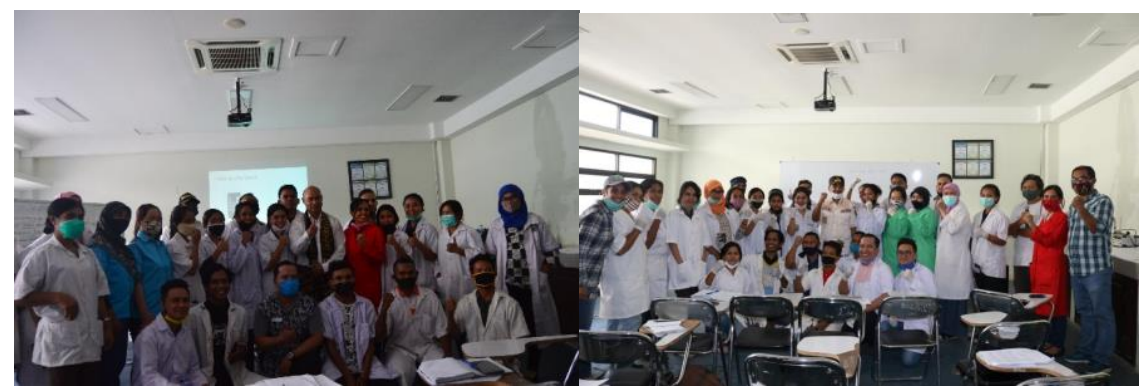

Gambar 8. Kunjungan Pemerintah. Gubernur NTT (kiri) dan Walikota Kupang (kanan).

Selain itu, peserta pelatihan juga diinformasikan mengenai kondisi swab load (banyaknya sampel yang diambil dan harus diperiksa) pada beberapa Rumah Sakit dan/atau Lab rujukan pemeriksaan COVID-19 yang cukup tinggi dengan rerata hari tunggu pemeriksan yang cukup lama. Hal ini turut mempertegas beberapa rekomendasi di antaranya: perbanyakan Lab Pemeriksaan COVID-19 berbasis regional NTT untuk mengurangi beban swab load,penggunaan pooled-test $\mathrm{qPCR}$ untuk pendeteksian orang tanpa gejala sehingga pemetaan tingkat risiko penularan COVID-19 dapat dilakukan secara lebih maksimal, evaluasi waktu isolasi/karantina pasien COVID-19 tanpa penyakit penyerta untuk mengurangi masa isolasi/karantina di fasilitas kesehatan yang terbatas sesuai dengan kondisi pasien dan penguatanscreening saat Pelacakan Kontak untuk memastikan penapisan orang yang tepat yang perlu diisolasi/dikarantina dan dilanjutkan dengan pemeriksaan sample swab (Ndoen, 2020). Selama pelatihan, para peserta juga dikunjungi oleh pihak Pemerintah Provinsi dan Kota (Gambar 8.).

\section{SIMPULAN}

Berdasarkan hasil observasi, dapat disimpulkan bahwa para peserta laboran telah minimal cukup menguasai teknik-teknik Biomolekuler Dasar selama pelatihan, yang terlihat dari keterampilan dalam menjalankan dan/atau menggunakan alat dan metode yang diajarkan. Keterampilan ini diharapkan dapat bermuara padapeningkatan kompetensi individu staf laboran ketika melakukan analisis sampel COVID-19, yang 
tentunya akan berkontribusi terhadap perolehan interpretasi hasil yang akurat, terpercaya dan dapat dipertanggungjawabkan.

\section{UCAPAN TERIMA KASIH}

Tim penulis ingin mengucapkan terima kasih yang sebesar-besarnya kepada Forum Academia NTT (FAN) dan Institute of Resource Governance and Social Change (IRGSC) Kupang yang telah melakukan perekrutan terhadap para laboran peserta pelatihan yang akan ditempatkan pada laboratorium Biomolekuler KesMas provinsi NTT. Ungkapan gratifikasi diberikan juga kepada pihak Politani Kupang yang telah bersedia memberikan fasilitas laboratorium bagi keberlangsungan pelatihan yang dimaksud. Kepada Pemerintah Provinsi, dalam hal ini Gubernur Nusa Tenggara Timur dan Dinas Kesehatan Provinsi NTT, apresiasi yang setinggi-tingginya diberikan atas dukungan proaktif terhadap 1) pencanangan program pemeriksaan sampel COVID-19 menggunakan metode pooled-test serta 2) penganggaran untuk dibangunnya Laboratorium Biomolekulerdilengkapi dengan segala fasilitas dan infrastruktur yang diperlukan. Diharapkan agar kedua hal tersebut dapat memberikan sumbangsih signifikan bagi agenda pemerintah dalam proses percepatan penanganan COVID-19 di lingkup provinsi NTT.

\section{DAFTAR PUSTAKA}

CDC. (2020, February 11). Labs. Centers for Disease Control and Prevention. https://www.cdc.gov/coronavirus/2019-ncov/lab/pooling-procedures.html

Chakraborty, S., \& Biswas, M. C. (2020). Impact of COVID-19 on the Textile, Apparel and Fashion Manufacturing Industry Supply Chain: Case Study on a Ready-Made Garment Manufacturing Industry (SSRN Scholarly Paper ID 3762220). Social Science Research Network. https://papers.ssrn.com/abstract=3762220

COVID-19 NTT - Sebaran Data. (2021, January 27). http://www.covid19.nttprov.go.id/home/data

Deckert, A., Bärnighausen, T., \& Kyei, N. N. (2020). Simulation of pooled-sample analysis strategies for COVID-19 mass testing. Bulletin of the World Health Organization, 98(9), 590-598. https://doi.org/10.2471/BLT.20.257188

Denny, T. N. (2020). Implementation of a Pooled Surveillance Testing Program for Asymptomatic SARS-CoV-2 Infections on a College Campus-Duke University, Durham, North Carolina, August 2-October 11, 2020. MMWR. Morbidity and Mortality Weekly Report, 69. https://doi.org/10.15585/mmwr.mm6946e1

DNA and RNA | Introduction to Chemistry. (n.d.). Retrieved January 27, 2021, from https://courses.lumenlearning.com/introchem/chapter/dna-and-rna/

dob. (2020, October 5). 3 Pekan PSBB Diperketat, Covid DKI Malah Melesat Pak Anies! Syariah. https://www.cnbcindonesia.com/syariah/20201005132218-29-191949/3-pekanpsbb-diperketat-covid-dki-malah-melesat-pak-anies

Fritsch, R. J., \& Krause, I. (2003). ELECTROPHORESIS. In B. Caballero (Ed.), Encyclopedia 
of Food Sciences and Nutrition (Second Edition) (pp. 2055-2062). Academic Press. https://doi.org/10.1016/B0-12-227055-X/01409-7

Health, C. for D. and R. (2020). Pooled Sample Testing and Screening Testing for COVID-19. FDA. $\quad$ https://www.fda.gov/medical-devices/coronavirus-covid-19-and-medicaldevices/pooled-sample-testing-and-screening-testing-covid-19

Herrera, H., Konradt, M., Ordoñez, G., \& Trebesch, C. (2020, November 6). The political consequences of the Covid pandemic: Lessons from cross-country polling data. VoxEU.Org. https://voxeu.org/article/political-consequences-covid-pandemic

Lee, P. Y., Costumbrado, J., Hsu, C.-Y., \& Kim, Y. H. (2012). Agarose Gel Electrophoresis for the Separation of DNA Fragments. Journal of Visualized Experiments: JoVE, 62. https://doi.org/10.3791/3923

Mackenzie, J. S., \& Smith, D. W. (2020). COVID-19: A novel zoonotic disease caused by a coronavirus from China: what we know and what we don't. Microbiology Australia, MA20013. https://doi.org/10.1071/MA20013

Mcleod, V. (2010, August 12). Biosafety Levels 1, 2, 3 \& 4 | Lab Manager. https://www.labmanager.com/lab-health-and-safety/biosafety-levels-1-2-3-4-19123

Mutesa, L., Ndishimye, P., Butera, Y., Souopgui, J., Uwineza, A., Rutayisire, R., Ndoricimpaye, E. L., Musoni, E., Rujeni, N., Nyatanyi, T., Ntagwabira, E., Semakula, M., Musanabaganwa, C., Nyamwasa, D., Ndashimye, M., Ujeneza, E., Mwikarago, I. E., Muvunyi, C. M., Mazarati, J. B., ... Ndifon, W. (2021). A pooled testing strategy for identifying SARS-CoV-2 at low prevalence. Nature, 589(7841), 276-280. https://doi.org/10.1038/s41586-020-2885-5

Ndoen, E. (2020, June 20). Menuju "New Normal” Nusa Tenggara Timur. Pelatihan Biomolekuler, Politani Kupang.

Nolan, T., Huggett, J., \& Sanchez, E. (2013). Good practice guide for the application of quantitative PCR (qPCR)First Edition 2013 (1st ed.).

Prawoto, N., Purnomo, E. P., \& Zahra, A. A. (2020). The Impacts of Covid-19 Pandemic on Socio-Economic Mobility in Indonesia. International Journal of Economics \& Business Administration (IJEBA), $\operatorname{VIII(3),~57-71.~}$

Qiagen, Q. (2012, June). RNeasy® Mini Handbook. http://webcache.googleusercontent.com/search?q=cache:mudLL5Z9LRcJ:www.bea.ki.se/ documents

Sapkota, A. (2020, November 1). Biosafety Cabinets- Definition, Classes (I, II, III) and Types. Microbe Notes. https://microbenotes.com/biosafety-cabinets/

SEP, S. E. P. (n.d.). LibGuides: SEPGuides: Science Education Partnership: Micropipet Kit. Retrieved July 1, 2020, from //libguides.fredhutch.org/SEP/sep/micropipet

Shereen, M. A., Khan, S., Kazmi, A., Bashir, N., \& Siddique, R. (2020). COVID-19 infection: Origin, transmission, and characteristics of human coronaviruses. Journal of Advanced Research, 24, 91-98. https://doi.org/10.1016/j.jare.2020.03.005

Sultan, B., White, J. A., Fish, R., Carrick, G., Brima, N., Copas, A., Robinson, A., Gilson, R., Mercey, D., \& Benn, P. (2016). The "3 in 1" Study: Pooling Self-Taken Pharyngeal, Urethral, and Rectal Samples into a Single Sample for Analysis for Detection of Neisseria gonorrhoeae and Chlamydia trachomatis in Men Who Have Sex with Men. Journal of Clinical Microbiology, 54(3), 650-656. https://doi.org/10.1128/JCM.02460-15

Using a micropipette-Diamantina Institute-University of Queensland. (2017, April 27). 
https://di.uq.edu.au/community-and-alumni/sparq-ed/sparq-ed-services/usingmicropipette

What is the difference between PCR and real-time PCR? | AAT Bioquest. (2020, February 4). https://www.aatbio.com/resources/faq-frequently-asked-questions/What-is-thedifference-between-PCR-and-real-time-PCR

WHO Western Pacific | World Health Organization. (2020, December 24). https://www.who.int/westernpacific

Working with RNA: Hints and Tips | Bioline| Meridian Bioscience. (2020). https://www.bioline.com/rna-hints-and-tips

World Health Organization (Ed.). (2004). Laboratory biosafety manual (3rd ed). World Health Organization. 